\title{
Variation of plasma cortisol levels in patients with depression after treatment with bilateral electroconvulsive therapy
}

\author{
Variação de cortisol plasmático em pacientes deprimidos após tratamento com \\ eletroconvulsoterapia bilateral
}

Daniel Fortunato Burgese, ${ }^{1}$ Débora Pastore Bassitt ${ }^{2}$

\begin{abstract}
Introduction: More than 60 years after the introduction of modern psychopharmacology, electroconvulsive therapy (ECT) continues to be an essential therapeutic modality in the treatment of mental disorders, but its mechanism of action remains unclear. Hormones play an essential role in the development and expression of a series of behavioral changes. One aspect of the influence of hormones on behavior is their potential contribution to the pathophysiology of psychiatric disorders and the mechanism of action of psychotropic drugs and ECT.

Objective: We measured blood levels of the hormone cortisol in patients with unipolar depression according to the Diagnostic and Statistical Manual of Mental Disorders, 4th edition (DSM-IV) and compared results with levels found in healthy adults.

Method: Blood cortisol levels were measured before the beginning of treatment with ECT, at the seventh session, and at the last session, at treatment completion. Depression symptoms were assessed using the Beck Depression Inventory (BDI).

Results: Cortisol levels remained stable in both men and women between the seventh and the last sessions of ECT; values ranged from $0.686 \pm 9.6330 \mathrm{~g} / \mathrm{dL}$ for women, and there was a mean decrease of $5.825 \pm 6.0780 \mathrm{~g} / \mathrm{dL}(p=0.024)$. Mean number of ECT sessions was 12. After the seventh and the last ECT sessions, patients with depression and individuals in the control group had similar cortisol levels, whereas BDI scores remained different. Conclusion: Cortisol levels decreased during ECT treatment. ECT seems to act as a regulator of the hypothalamic-pituitaryadrenal axis.
\end{abstract}

Keywords: Depression, cortisol, ECT, endocrine disorders, hypothalamic-pituitary-adrenal axis.

\section{Resumo}

Introdução: Mais de 60 anos após a introdução da moderna psicofarmacologia, a eletroconvulsoterapia (ECT) continua essencial para o tratamento de distúrbios mentais, mas seu mecanismo de ação ainda não é totalmente conhecido. Certos hormônios têm um papel fundamental no desenvolvimento e expressão de uma série de alterações comportamentais. Um aspecto da influência dos hormônios nos comportamentos é sua contribuição potencial para a patofisiologia dos distúrbios psiquiátricos e o mecanismo de ação de psicotrópicos e da ECT.

Objetivo: Os níveis do hormônio cortisol no sangue foram medidos em pacientes com depressão unipolar classificados de acordo com a $4^{a}$ edição do Manual Estatístico e Diagnóstico de Transtornos Mentais (DSM-IV), e os resultados foram comparados com os níveis encontrados em adultos saudáveis. Métodos: Os níveis de cortisol no sangue foram medidos antes do início do tratamento com ECT, na sétima e na última sessão, após a conclusão do tratamento. Os sintomas de depressão foram avaliados usando o Inventário de Depressão de Beck (BDI).

Resultados: Os níveis de cortisol permaneceram estáveis tanto nos pacientes masculinos quanto femininos entre a sétima e a última sessão de ECT; os valores variaram $0,686 \pm 9,6330 \mathrm{~g} /$ $\mathrm{dL}$ entre as pacientes femininas, e houve uma diminuição de $5,825 \pm 6,0780 \mathrm{~g} / \mathrm{dL}(\mathrm{p}=0,024)$. O número médio de sessões de ECT foi 12. Após a sétima e a última sessão de ECT, os níveis de cortisol nos pacientes com depressão e nos indivíduos no grupo controle foram semelhantes, enquanto os resultados da escala BDI permaneceram diferentes.

Conclusão: Os níveis de cortisol diminuíram durante o tratamento com ECT. A ECT parece atuar como reguladora do eixo hipotalâmico-hipofisário-adrenal.

Descritores: Depressão, cortisol, ECT, distúrbios endócrinos, eixo hipotalâmico-hipofisário-adrenal.

\footnotetext{
${ }^{1}$ Department of Psychiatry, Instituto de Assistência Médica ao Servidor Público Estadual (IAMSPE), São Paulo, SP, Brazil. ${ }^{2}$ Department of Psychiatry, IAMSPE, São Paulo, SP, Brazil. Institute of Psychiatry, Hospital das Clínicas da Faculdade de Medicina da Universidade de São Paulo, São Paulo, SP, Brazil.

Financial support: none.

Submitted Jul 18 2014, accepted for publication Nov 19 2014. No conflicts of interest declared concerning the publication of this article.

Suggested citation: Burgese DF, Bassitt DP. Variation of plasma cortisol levels in patients with depression after treatment with bilateral electroconvulsive therapy. Trends Psychiatry Psychother. 2015;37(1):27-36. http://dx.doi.org/10.1590/2237-6089-2014-0031. Epub Jan 30, 2015.
} 


\section{Introduction}

The World Health Organization estimates that depression will be the second leading cause of global illness by 2020. Severe depression may significantly decrease quality of life and lead to death by suicide, for which the risk rate is $6 \%$ to $15 \%$ among patients with this affective disorder. It may also increase mortality associated with general medical conditions, most notably cardiovascular disease. ${ }^{1}$

More than 60 years after the introduction and use of modern psychopharmacology, electroconvulsive therapy (ECT) continues to be an essential therapeutic modality in the treatment of mental illnesses. The effectiveness of ECT in treating depression has been demonstrated in numerous studies conducted over the past decades. ${ }^{2}$

The use of pharmacologically induced seizures to treat mental illness was first described by Laszlo Meduna in 1934, but it was only in 1938 that Ugo Cerletti and Lucio Bini used an electric current, or electroshock, for the treatment of patients with depression. ${ }^{3}$ ECT has been associated with the beginning of modern biological psychiatry.

Research has improved ECT efficacy and safety and reduced its side effects. Variations of antidepressant brain stimulation techniques, such as transcranial magnetic stimulation, magnetic seizure therapy, direct current stimulation, vagus nerve stimulation, and deep brain stimulation, entered the field of modern psychiatry. None of these techniques proved to be superior to ECT in terms of action time and response rates. Although ECT is the oldest surviving biological therapy in psychiatry and the most effective short-term treatment for major depression, it still faces constant skepticism. ${ }^{4}$

The precise mechanism of ECT action remains unknown, and the greatest difficulty in understanding ECT function lies in the induction of a generalized seizure by an electric current that passes through the brain. It is associated with multiple sequences of biochemical and neuroendocrine changes, which are very difficult to isolate. It is also difficult to assign treatment results to a single specific therapeutic effect. ${ }^{5}$

Hormones play an essential role in the development and expression of a series of behavioral changes. Of all endocrine axes, the hypothalamic-pituitary-adrenal (HPA) axis has been the most studied in psychiatry. Corticosteroids, a class of steroid hormones produced in the adrenal cortex, act in a wide range of systems and are essential for life because of their multifaceted effect. The HPA axis is a regulatory system that integrates endocrine and neurological functions. The neurosecretory cells of the paraventricular nucleus (PVN) of the hypothalamus secrete corticotropin releasing factor (CRF) and arginine vasopressin (AVP) into the pituitary portal blood. In the adenohypophysis, or anterior pituitary, they stimulate the release of the adrenocorticotrophic hormone (ACTH), which leads to the release of cortisol by the adrenal cortex. Cortisol is the final product of the HPA axis, which has central and peripheral functions mediated by at least two types of specific receptors: type 1 , or high-affinity mineralocorticoid receptor (MR), first described in the central nervous system by McEwen et al. ${ }^{6}$; and type 2, or low-affinity glucocorticoid receptor (GR). ${ }^{7}$ Glucocorticoids interact with their receptors in multiple target tissues, including the HPA axis, and are responsible for the negative feedback of ACTH secretion by the pituitary. ${ }^{8}$

Recent theories associate depression with physiological changes in the functioning of the HPA axis and serotonergic neurotransmission. The high cortisol levels found in plasma, urine and cerebrospinal fluid of people with depression, a sign of HPA axis hyperfunction, are some of the most consistent findings in psychiatry. ${ }^{7,9}$

Studies about HPA axis activity in patients with depression found an increased cortisol response to $\mathrm{ACTH}$ stimulation, decreased cortisol response to hypoglycemia, decreased ACTH response to stimulation with $\mathrm{CRH}$ and resistance to cortisol suppression by dexamethasone response. ${ }^{10,11}$ These responses promote autonomic and behavioral changes associated with depression, which suggests that there is a disruption in the negative feedback of endogenous cortisol. Furthermore, there is an imbalance between GR and MR receptors in patients with depression, or decreased activity of $G R$ receptors and increased activity of $\mathrm{MR}^{12}$ receptors. According to Stefos ${ }^{13}$ and Nelson \& Davis, ${ }^{14}$ psychotic depression is more closely associated with hypercortisolism and nonsuppression of cortisol. According to Saraiva et al., ${ }^{7}$ there are two models of association between depression and changes in physiological cortisol levels. In one model, primary factors contribute to the primary event of hypercortisolism. These factors are trauma and biological vulnerability, which may trigger depressive symptoms. Excessive cortisol increases the intensity of affective symptoms and may promote an even greater increase in plasma cortisol levels. In the first model, the affective symptoms of depression generate harmful effects in the hippocampus, such as inhibition of neurogenesis and hippocampal volume loss, which may lead to cognitive symptoms. In the second model, the triggering element of the cognitive effects may be hypercortisolism. ${ }^{15}$

Acute ECT has been consistently associated with improvement in plasma levels of cortisol. ${ }^{16-19}$ Studies have found that the levels of cortisol and ACTH measured 
before treatment with ECT do not change after a series of ECT sessions, whereas other studies have revealed a fall in the levels of cortisol. ${ }^{16,18,20-26}$

\section{Objective}

Changes in the HPA axis are a characteristic of depression. This study measured plasma levels of the hormone cortisol in patients with unipolar depression according to the Diagnostic and Statistical Manual of Mental Disorders, 4th edition (DSM-IV). ${ }^{27}$ Measurements were made in the beginning of the treatment with ECT, at the seventh session and after the completion of a therapeutic course of treatment using ECT. After that, depression symptoms were assessed using the Beck Depression Inventory (BDI), and findings were compared with cortisol blood levels in healthy volunteers.

\section{Method}

Individuals that met diagnostic criteria for major depressive disorder according to the DSM-IV and had no psychiatric or neuroendocrine comorbidities were invited to participate in the study. Participants had no other axis I diagnoses and did not use alcohol or other substances in the previous year. Exclusion criteria were clinical psychiatric comorbidities and neuroendocrinologic changes that might affect HPA axis. All patients, guardians and volunteers read and signed a Consent Form for Participation in Clinical Research approved by the Research Ethics Committee of Instituto de Assistência Médica ao Servidor Público Estadual (IAMSPE) (protocol no. 112/10).

All individuals underwent clinical and cardiac evaluations before treatment with ECT, and all were physically healthy. Psychotropic medications were discontinued before the beginning of ECT. The washout period was calculated for each individual according to the half-life of their psychotropic medication, and five days was the shortest time to the beginning of the treatment. All participants remained hospitalized in psychiatric wards during the treatment with ECT and did not resume use of any psychotropic drugs, except bromazepam 3 mg for night sedation, if needed, during all the study time.

The severity of depressive symptoms was classified using the BDI. Values below 10 points were scored as minimum or no depression; 10 to 18 points, mild to moderate depression; 19 to 29 points, moderate to severe depression; and 30 to 63 points, severe depression.
Individuals in the control group, recruited among hospital employees, were matched for sex and age. Peripheral blood was collected from the upper limb to measure morning cortisol levels, and the BDI was administered. Individuals were excluded if they scored more than 10 points in BDI, or had clinical psychiatric comorbidities or neuroendocrinologic conditions that might affect the HPA axis.

In the group of patients with depression, cortisol was measured during the morning after awakening, and the BDI scale was applied at three time points during the treatment with ECT: the first at the time of the first ECT session, before the procedure; the second, after the seventh ECT session; and the third, after the last ECT session. Biological material was collected through the same venous access used for the administration of anesthetics for ECT by the nursing and medical teams. Laboratory samples of biological material were analyzed in the Department of Clinical Analyses of IAMSPE using an Immulite 2000 XPISIEMENS analyzer.

For ECT, general anesthesia was induced using thiopental sodium, a muscle relaxant (succinylcholine) and hyperventilation. All patients received bitemporal application of ECT using a Somatics-Thymatron IV system and ECT pulses of $0.5 \mathrm{~ms}$. Seizure threshold was estimated in the first session based on the age of the patient and individual adjustments to obtain a seizure lasting between 25 to $30 \mathrm{~s}$. Sessions were held twice a week, and the total number of sessions was determined by the attending physician based on the clinical assessment of response to treatment.

\section{Results}

In the statistical analysis of the results, a chi-square test was used to evaluate the association between categorical variables and quantitative variables. The Kolgomorov-Smirnov test was used to check normal distribution, and the $t$ test, to analyze the differences between groups at the same time point. The nonparametric Mann-Whitney test was used to analyze the differences between two groups, and the KruskallWallis test, to analyze the four groups (group and sex; group and age group) at the same time point. For longitudinal comparisons, the Wilcoxon test was used to compare two time points, and the Friedman test, to compare three time points. For the correlations between variables, we used the Spearman correlation coefficient, which evaluated the correlations between variables, and the Bonferroni correction, used for multiple comparisons. The level of significance was set at $p \leq 0.05$. 


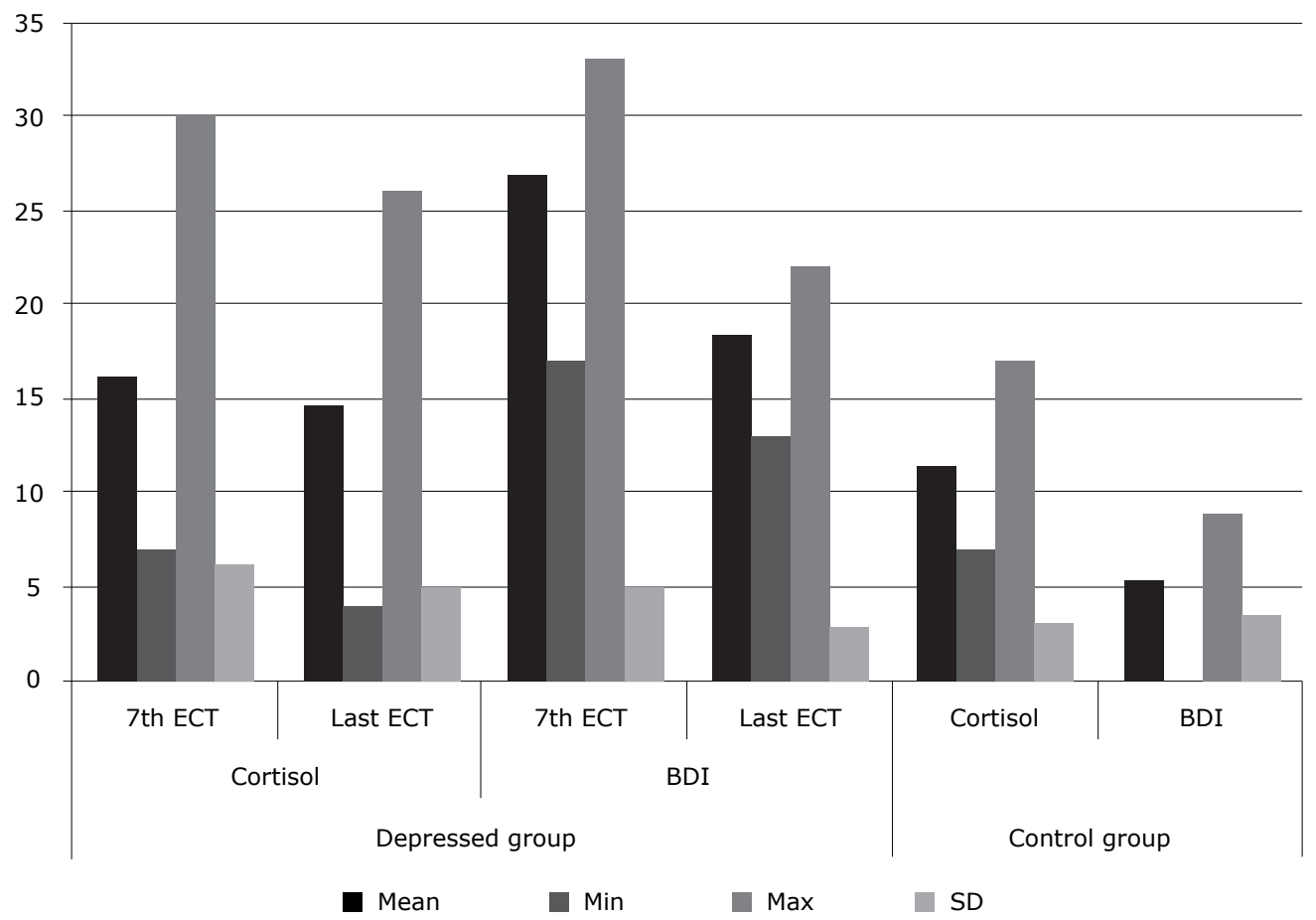

Figure 1 - Cortisol levels and Beck Depression Inventory (BDI) scores in depressed group on the 7th and last electroconvulsive therapy (ECT) session compared with results for the control group; baseline cortisol, $\mathrm{p}=0.008$; BDI, $\mathrm{p}<0.001$. At the time of the last ECT session, the results for cortisol levels were $p \geq 0.05$ between groups. Max = maximum; Min= minimum; $S D=$ standard deviation.

The comparison of the results of the group of patients with depression and of the control group revealed that initially only sex and age were the same between groups, whereas BDI scores and baseline cortisol levels were significantly different: $p=0.008$ for baseline cortisol level and $p<0.001$ for BDI scores. In the seventh and final ECT session, the groups had similar cortisol levels ( $p \geq 0.05$ ), whereas BDI scores remained different at the three time points, but decreased progressively towards the values found for the control group ( $p=0.01$ ) (Figure 1 ).

Mean age in the control group was $54.10 \pm 12.324$, mean baseline cortisol level was $11.40 \pm 3.098 \mu \mathrm{g} / \mathrm{dL}$ and mean initial BDI score was $5.40 \pm 3.565$ points on the initial BDI scale Sex and age distribution was equal, and $p$ was $\leq 0.05$ for the comparison of cortisol levels and BDI scores (Table 1).

Eleven participants completed the study and had baseline and post-ECT results. Seven were women, there were no differences in sex and age distribution. Mean age was $59.5 \pm 10.93$ years, mean baseline cortisol level was $16.36 \pm 5.065 \mu \mathrm{g} / \mathrm{dL}$, and mean BDI score was 44.82 \pm 8.424 (Table 1 ).

Table 1 - Distribution of age, baseline cortisol levels $(\mu \mathrm{g} / \mathrm{dL})$ and Beck Depression Inventory scores in the control group and in the depressed group (level of significance: $p \leq 0.05$ )

\begin{tabular}{|c|c|c|c|}
\hline & Control group & Depressed group & $\mathbf{p}$ \\
\hline \multicolumn{4}{|l|}{ Age } \\
\hline Mean & 54.1 & 59.5 & \multirow{4}{*}{$p \geq 0.00$} \\
\hline Minimum & 42 & 37 & \\
\hline Maximum & 81 & 79 & \\
\hline Standard deviation & 12.324 & 10.93 & \\
\hline \multicolumn{4}{|l|}{ Cortisol level $(\mu \mathrm{g} / \mathrm{dL})$} \\
\hline Mean & 11.4 & 16.36 & \multirow{4}{*}{$p=0.008$} \\
\hline Minimum & 7 & 11 & \\
\hline Maximum & 17 & 26 & \\
\hline Standard deviation & 3.098 & 5.07 & \\
\hline \multicolumn{4}{|l|}{ BDI score } \\
\hline Mean & 5.4 & 44.82 & \multirow{4}{*}{$p<0.001$} \\
\hline Minimum & 0 & 34 & \\
\hline Maximum & 9 & 63 & \\
\hline Standard deviation & 3.565 & 8.42 & \\
\hline
\end{tabular}

30 - Trends Psychiatry Psychother. 2015;37(1) 


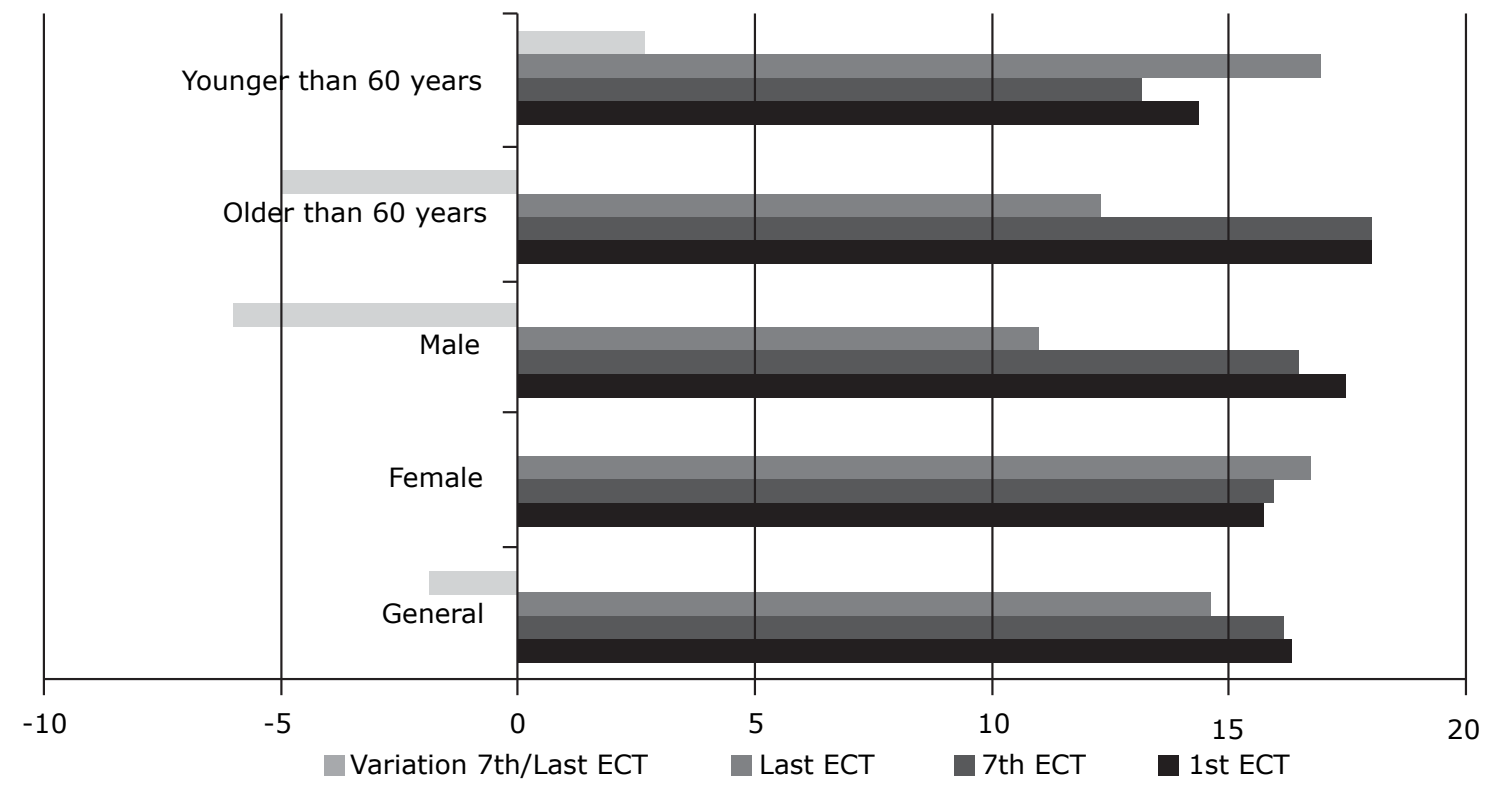

Figure 2 - Comparison of cortisol levels $(\mu \mathrm{g} / \mathrm{dL})$ in the depressed group in the subgroups older and younger than 60 years at the time of the 1 st and 7th ECT session $(p=0.017)$, and variation in the intervals between the 7th and the last ECT sessions $(p=$ $0.030)$; the comparison between sex and age was not statistically significant.

In the depressed group, there were no significant differences between age and sex distribution. Women had a cortisol variation of $0.843 \pm 6.9916 \mu \mathrm{g} / \mathrm{dL}$ between the first and the last ECT session, while men had a decrease of $6.725 \pm 4.0219 \mu \mathrm{g} / \mathrm{dL}$ ) in the same period of analysis, and this difference between sexes was significant $(p=0.024)$ (Figure 2).

Cortisol levels remained stable in both sexes between the seventh and the last ECT sessions; variation values were $0.686 \pm 9.6330 \mu \mathrm{g} / \mathrm{dL}$ for women, and mean decrease was $5.825 \pm 6.0780 \mu \mathrm{g} / \mathrm{dL}(\mathrm{p} \geq 0.05)$, but the difference was not statistically significant (Table 2, Figure 3).

The subgroup of individuals 60 years and older in the depressed group had a greater variation in cortisol levels between the first and the last ECT session ( $p=0.017$ ) and the seventh and the final session ( $p=0.030$ ) than patients younger than 60 years (Figure 2). The comparison of the subgroup of individuals 60 years and older according to sex revealed no statistical differences. The analysis of variables that were correlated revealed that the older the individuals in the depressed group, the greater the difference in the variation of cortisol levels between the last and the first ECT sessions. Also, the higher the cortisol level at the first ECT session, the greater the difference in BDI scores between the first and the seventh ECT sessions (Table 2).

BDI scores decreased progressively and were significantly different at the three time points $(p=0.003)$.

Some variables were correlated, and findings of the comparisons between age and cortisol variation from the beginning to the end of the treatment with ECT were significant.

The older the patient, the greater the difference between cortisol levels at the first and the last ECT session; the higher the BDI scores at the first time point, the greater the cortisol level. There was also a correlation between baseline cortisol levels and BDI score differences at the first and the seventh session. The comparison of the depressed and control groups revealed that only sex and age at baseline were the same between groups, whereas BDI scores and baseline cortisol levels were significantly different (baseline cortisol: $p=0.008$; BDI: $p<0.001)$. At the seventh and at the final ECT sessions, the groups had similar cortisol levels ( $p \geq 0.05$ ), whereas BDI scores remained different between groups at the three different time points, but there was a progressive reduction towards levels in the control group $(p=0.01)$ (Figure 3 ). 
Table 2 - Distribution of absolute values of baseline cortisol levels ( $\mu \mathrm{g} / \mathrm{dL})$, BDI scores, variation of cortisol level and BDI score between the first, seventh and last session in the depressed group according to age

\begin{tabular}{|c|c|c|c|c|c|c|c|c|c|c|c|c|c|}
\hline & \multicolumn{4}{|c|}{$\begin{array}{c}\text { Cortisol level } \\
(\mu \mathrm{g} / \mathrm{dL})\end{array}$} & \multicolumn{3}{|c|}{ BDI score } & \multicolumn{3}{|c|}{$\begin{array}{c}\text { Variation of the cortisol } \\
\text { dosage }\end{array}$} & \multicolumn{3}{|c|}{ Variation of the BDI score } \\
\hline & Age & $\begin{array}{l}\text { 1st } \\
\text { ECT }\end{array}$ & $\begin{array}{l}\text { 7th } \\
\text { ECT }\end{array}$ & $\begin{array}{l}\text { Last } \\
\text { ECT }\end{array}$ & $\begin{array}{l}\text { 1st } \\
\text { ECT }\end{array}$ & $\begin{array}{l}\text { 7th } \\
\text { ECT }\end{array}$ & $\begin{array}{l}\text { Last } \\
\text { ECT }\end{array}$ & $\begin{array}{l}\text { 7th/1st } \\
\text { ECT }\end{array}$ & $\begin{array}{l}\text { Last/ } \\
\text { 7th ECT }\end{array}$ & $\begin{array}{l}\text { Last/1st } \\
\text { ECT }\end{array}$ & $\begin{array}{l}\text { 7th/1st } \\
\text { ECT }\end{array}$ & $\begin{array}{c}\text { Last/7th } \\
\text { ECT }\end{array}$ & $\begin{array}{l}\text { Last/1st } \\
\text { ECT }\end{array}$ \\
\hline \multicolumn{14}{|l|}{ General } \\
\hline Mean & 59.55 & 16.36 & 16.18 & 14.64 & 44.82 & 26.91 & 18.45 & -0.318 & -1 & -1.909 & 17.91 & 8 & 26.36 \\
\hline Minimum & 37 & 11 & 7 & 4 & 34 & 17 & 13 & -5.8 & -11.9 & -9 & 6 & 3 & 15 \\
\hline Maximum & 79 & 26 & 30 & 26 & 63 & 33 & 22 & 6.8 & 18.8 & 13.1 & 32 & 16 & 48 \\
\hline $\mathrm{SD}$ & 10.93 & 5 & 6 & 5 & 8 & 5 & 2.911 & 4 & 8 & 6 & 7 & 5 & 8 \\
\hline \multicolumn{14}{|l|}{ Women } \\
\hline Mean & 56.71 & 15.71 & 16 & 16.71 & 45.71 & 28.71 & 18.86 & 0.157 & 0.686 & 0.843 & 17 & 9.86 & 26.86 \\
\hline Minimum & 37 & 11 & 7 & 12 & 34 & 22 & 15 & -5.8 & -11.5 & -7.4 & 6 & 3 & 15 \\
\hline Maximum & 79 & 26 & 30 & 26 & 63 & 33 & 22 & 6.8 & 18.8 & 13.1 & 32 & 16 & 48 \\
\hline SD & 12.996 & 5 & 7 & 4 & 10.291 & 3 & 2.673 & 5.3727 & 9 & 6.9916 & 9 & 5 & 11 \\
\hline \multicolumn{14}{|l|}{ Men } \\
\hline Mean & 64.50 & 17.5 & 16.5 & 11 & 43.25 & 23.75 & 17.75 & -1 & -5 & -6 & 19.5 & 6 & 25.5 \\
\hline Minimum & 63 & 13 & 11 & 4 & 39 & 17 & 13 & -4.3 & -11.9 & -9 & 15 & 3 & 22 \\
\hline Maximum & 69 & 25 & 24 & 17 & 48 & 33 & 21 & 2.9 & 2.6 & -7 & 23 & 13 & 28 \\
\hline SD & 3.0 & 5.26 & 5 & 5 & 4 & 6 & 3 & 3 & 6 & 4 & 3 & 4 & 2 \\
\hline \multicolumn{14}{|l|}{$\begin{array}{l}\text { Older than } 60 \\
\text { years }\end{array}$} \\
\hline Mean & 66.83 & 18 & 18 & 12.33 & 45.5 & 26.17 & 17 & 0.6 & -6.5 & -5 & 19 & 8.5 & 27.83 \\
\hline Minimum & 63 & 12 & 11 & 4 & 37 & 17 & 13 & -4.3 & -11.9 & -9 & 6 & 3 & 17 \\
\hline Maximum & 79 & 26 & 30 & 18 & 63 & 33 & 21 & 4 & 2.6 & -0.1 & 32 & 16 & 48 \\
\hline SD & 6 & 6 & 6.976 & 5 & 9 & 6 & 3 & 3 & 5.3468 & 4 & 8 & 5 & 10.647 \\
\hline \multicolumn{14}{|c|}{$\begin{array}{l}\text { Younger than } 60 \\
\text { years }\end{array}$} \\
\hline Mean & 50.80 & 14.4 & 13.2 & 17 & 44 & 27.8 & 19 & -1.42 & 4 & 2.68 & 16.2 & 8.4 & 24.6 \\
\hline Minimum & 37 & 11 & 7 & 12 & 34 & 22 & 17 & -5.8 & -2.8 & -7 & 10 & 3 & 15 \\
\hline Maximum & 58 & 18 & 18 & 26 & 56 & 33 & 22 & 6.8 & 18.8 & 13.1 & 25 & 16 & 34 \\
\hline SD & 8.497 & 5.05 & 4 & 5 & 7 & 4 & 2 & 5.6936 & 9 & 7 & 5 & 5 & 6 \\
\hline
\end{tabular}

$\mathrm{BDI}=$ Beck Depression Inventory; $\mathrm{ECT}=$ electroconvulsive therapy; SD = standard deviation.

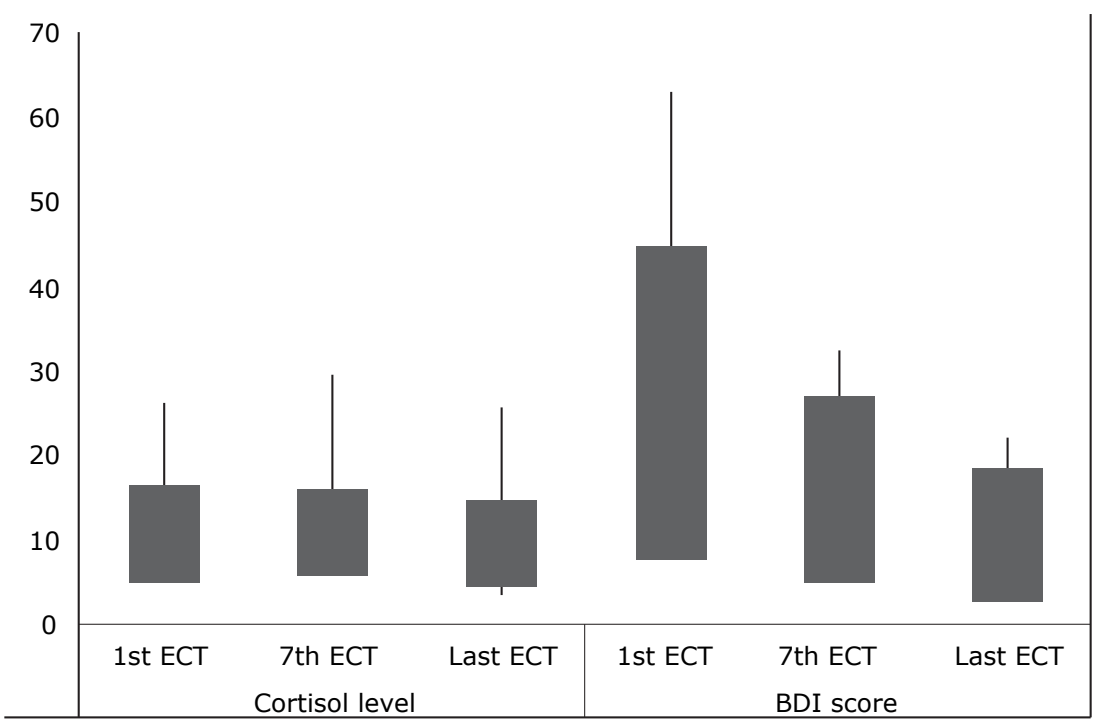

Figure 3 - Cortisol levels $(\mu \mathrm{g} / \mathrm{dL}$ ) and Beck Depression Inventory (BDI) scores in absolute values in the depressed group. Cortisol levels remained stable in general $(p \geq 0.05)$. BDI scores decreased at the three time points $(p=0.003)$. ECT = electroconvulsive therapy. 


\section{Discussion}

Neuroendocrine studies have found variations in cortisol levels and changes in the hypothalamichypophysis-adrenal axis of patients with depression. ${ }^{28-32}$ Although these biological changes are some of the wellestablished theses in psychiatry, their psychopathological and physiological implications are still unclear.

Abrams \& Taylor, $^{33}$ Fink \& Nemeroff ${ }^{34}$ and Grover et al. ${ }^{3}$ suggested that ECT corrects a deregulation of neuropeptides by means of diencephalic stimulation. They found an increased production and release of several neuropeptides, some of which had transient antidepressant effects, as well as vegetative and neuroendocrine deregulation, features of depression that are mediated by core brain structures and that are improved by treatment with ECT. Their studies found increased levels of corticotropin, cortisol, prolactin, oxytocin, vasopressin, beta-endorphin and growth hormone after ECT.

The effects of corticosteroids on serotonergic receptors (5-HT) may have an important role in vegetative and affective functions: in experiments with laboratory animals, chronically stressed animals had high levels of circulating corticosteroids, decreased levels of 5-HT messenger RNA and predominance of depressive behaviors, such as less locomotion, which reduces exploratory attitudes and leads to anorexia. However, after five to seven days of continuous exposure to stress, the activity of the 5-HT receptors and behaviors were back to normal, and adaptive responses were interrupted by repeated administration of corticosterone, but facilitated by the administration of antiglucocorticoids. ${ }^{7}$

According to Wolkowitz \& Reus, ${ }^{35}$ hypercortisolism, frequent in patients with major depression, has been associated with various behavioral changes, such as sleep disorders, lassitude, decreased attention and libido, psychomotor disorders, anxiety and suicide ideation. However, the interpretation of these data is difficult because the studies under analysis demonstrated that not all patients with depression have hypercortisolism, and not all patients with hypercortisolism have depression. Keller et al. ${ }^{36}$ reported that the patients with depression who attempt suicide violently have higher cortisol levels than patients with depression and non-violent suicide attempts, and suggested that deregulation of the HPA axis may be a factor of violent suicide behavior. Cortisol levels are higher in brain spinal fluid, but return to normal after treatment and recovery from depression. ${ }^{37}$

Markianos et al. ${ }^{38}$ studied a group of 13 control individuals and 11 men with depression undergoing eight to 13 ECT sessions and their variation of cortisol levels. Baseline cortisol levels were $30 \%$ greater in patients than in controls, but there were no differences from baseline values after ECT. McKay \& Zakzanis ${ }^{39}$ conducted a metaanalysis of 34 studies and 1049 patients with depression treated with ECT, transcranial magnetic stimulation and antidepressants and compared cortisol levels in saliva, urine and blood. They found that treatment type and cortisol levels did not have any impact on pre- and post-treatment levels, but that depression subtype and disease duration might contribute to changes in cortisol levels. The melancholy subtype, for example, had larger variations in cortisol levels before and after treatment.

Zis et al. ${ }^{28}$ compared cortisol and prolactin levels in 10 patients with depression treated with unilateral ECT using high and low voltage. They found that seizure duration did not affect cortisol and prolactin levels, but cortisol levels were significantly higher in the high voltage subgroup than in the low voltage group. Ozsoy et al. ${ }^{40}$ examined blood samples collected two days before, 10 minutes after the first session and three days after the end of ECT from patients with depression, and compared findings with the results of a blood sample collected from individuals in the control group. They found that baseline cortisol levels did not differ significantly between patients and controls, but that cortisol levels were significantly lower in the group of patients after ECT completion.

Acute treatment with ECT affected ACTH, cortisol, and prolactin levels, which suggests that the ECT regulates serum levels of the hormones of the HPA axis by stimulating the hypothalamus to function normally. ${ }^{18,37,41}$

In this study we investigated the changes in plasma cortisol levels throughout ECT treatments and analyzed BDI scores. Cortisol levels decreased as ECT treatment progressed. Cortisol levels were greater than those of the control group at baseline, but at the 7th ECT session, cortisol levels were similar to those of the control group. Values were significantly greater in the group of patients older than 60 years than among individuals in the control group. There were no statistically significant differences between men and women 60 years or older in the depressed group. Reductions of cortisol levels after ECT specifically in elderly patients with depression are not a frequent finding in the literature.

According to Keller et al., ${ }^{36}$ high cortisol levels are found in depression, and levels are higher in psychotic depression. There is evidence that this is associated with age, and elderly individuals with depression tend to have higher cortisol levels. Physiological aging is associated with a relative increase in the activity of the HPA axis, associated with a reduction of mineralocorticoid and glucocorticoid receptors. Sapolsky et al.42,43 found consistent evidence that the rupture of glucocorticoid levels resulted in mood and cognition disorders, neurophysiological changes, alterations in the activity of neurotransmitters and neuroanatomic variations. 
Pariante \& Miller $^{44}$ and Soskin et al. ${ }^{45}$ found that physiological stress responses activate the sympathetic nervous system, which releases catecholamine adrenaline and norepinephrine into the portal circulation, followed by HPA-axis activation, which stimulates the release of ACTH by the hypophysis and the consequent release of glucocorticoids by the adrenal glands. Depression is characterized by hyperactivity of the HPA axis and insensitivity of glucocorticoid brain receptors. As a result, inhibition is deficient because of the negative feedback to stress.

Von Cauter et al. ${ }^{46}$ and $\operatorname{Harman}^{47}$ suggest that $\mathrm{ACTH}$ and cortisol secretions are age-related, as mean 24 -hour serum cortisol level is $20 \%$ to $50 \%$ greater in men and older women, and that serum cortisol levels have similar increases in response to fasting in elderly men and young people. Serum cortisol responses to stress are prolonged in older individuals, possibly due to changes in glucocorticoid receptors.

The answer to whether depression is the cause or consequence of hypercortisolism is hard. Depression has been associated with chronic high cortisol levels because of the deregulation of the HPA axis and the reduction of hippocampal volume in humans after recurrent episodes of depression. 5,48

High cortisol levels may impair brain function because of mechanisms such as changes in the brain glucose metabolism, which potentiate the toxic effect of excitatory amino acids, such as glutamate, and block the action of neurotrophic factors that are crucial for the recovery of brain damage. ${ }^{49}$ The area of hippocampal formation is rich in mineralocorticoids and in glucocorticoids and has receptors that maintain the baseline HPA axis and the negative feedback regulation of glucocorticoids during the response to stress. Therefore, the hippocampus is particularly vulnerable to the effects of stress and depression.

According to O'Brien et al., ${ }^{50}$ high cortisol levels during depression may be associated with cognitive changes, and chronic hypercortisolism in depression may cause damage to the hippocampus, which explains why these deficiencies persist in individuals with depression even after the affective symptoms have disappeared. This hypothesis would justify the findings in our study, in which patients with depression had high BDI scores even after ECT and clinical improvement. Patients with depression are usually referred to treatment with ECT when refractory to drug treatments, which would explain the fact that BDI scores are elevated even after the end of treatment with ECT and that there are residual symptoms even when cortisol levels are similar to those found in the control group. Our findings of a reduction of cortisol levels after ECT sessions are consistent with the findings reported by Aperia et al., ${ }^{16}$ Aperia et al.. ${ }^{20}$ Weizman et al. ${ }^{23}$ and Ozsoy et al. ${ }^{40}$

Ozsoy et al. ${ }^{40}$ suggested that the mechanism of action of ECT might be explained by the fact that it changes the instability of levels of neuroactive steroids that affect gamma-aminobutyric acid (GABA) antagonists, such as dehydroepiandrosterone (DHEAS), and GABA agonists, as testosterone and progesterone. In depression, estrogen and testosterone levels are physiological unstable, which contributes to the symptoms of depression, such as sexual dysfunction and reduced energy. Moreover, ECT might contribute to clinical improvement by means of regular activation of neuroactive steroids. In their study, high DHEAS levels were detected in male patients with depression, whereas no changes were found in women. After ECT, DHEAS elevations were less marked in men and remained stable in women, which indicated an inverse correlation between DHEAS and cortisol levels after ECT. These data are consistent with the findings in our study, in which cortisol levels differed between male and female patients after treatment with ECT. We believe that glucocorticoid receptors in elderly populations with depression are disrupted and that ECT may reestablish the function of the HPA axis.

Cortisol levels decrease during treatments using ECT, which suggests that ECT acts as a regulator of the HPA axis. It remains uncertain, however, whether hypercortisolism is an epiphenomenon or a direct contribution to depressive symptoms and biochemical changes in major depression.

The evaluation of our results should take into consideration study limitations, and our findings should be classified as preliminary. The association of depression severity with hypercortisolism mechanisms is not warranted for several reasons. First, our sample size was too small to establish a correlation between depression severity, cortisol levels and possible changes of the hippocampal volume. Second, cortisol levels in elderly populations were not analyzed because our sample of patients 60 years or older was small. Studies to evaluate these variables should include a larger sample of patients with depression for a better understanding of the physipathology of depression and the correlations of cortisol levels before and after treatments with ECT.

Recent studies have contributed to the improvement of our knowledge about possible mechanisms of action of ECT and to the development of safe and well-tolerated treatments, but some fundamental mechanisms remain unclear. Although the precise mechanism of action of ECT has not been described, 
this highly effective therapeutic option should not be seen only as a last choice for the treatment of depression.

\section{References}

1. Lisanby $\mathrm{SH}$. Electroconvulsive therapy for depression. $\mathrm{N}$ Engl J Med. 2007;357:1939-45.

2. Antunes PB, Rosa MA, Belmonte-de-Abreu PS, Lobato MIR, Fleck MP. Eletroconvulsoterapia na depressão maior: aspectos atuais. Rev Bras Psiquiatr. 2009;31:S26-S33.

3. Grover S, Mattoo SK, Gupta N. Theories on mechanism of action of electroconvulsive therapy. German J Psychiatry. 2005;8:70-84

4. Merkl A, Heuser I, Bajbouj M. Antidepressant electroconvulsive therapy: mechanism of action, recent advances and limitations. Exp Neurol. 2009;219:20-6.

5. Madsen TM, Treschow A, Bengzon J, Bolwig TG, Lindvall $O$, Tingstrom A. Increased neurogenesis in a model of electroconvulsive therapy. Biol Psychiatry. 2000;47:1043-9.

6. McEwen BS, Davis PG, Parsons B, Pfaff DW. The brain as a target for steroid hormone action. Annu Rev Neurosci. 1992;2:65112.

7. Saraiva EM, Fortunato JMS, Gavina C. Oscilações do cortisol na depressão e sono/vigília. Rev Port Psicossomática. 2005;7:89-100.

8. Juruena MF, Cleare AJ, Pariante CM. O eixo hipotálamo-pituitáriaadrenal, a função dos receptores de glicocorticóides e sua importância na depressão. Rev Bras Psiquiatr. 2004;26:189201.

9. Alheira FV, Brasil MAA. O papel dos glicocorticóides na expressão dos sintomas de humor: uma revisão. Rev Psiquiatr Rio Gd Sul. 2005;27:177-86.

10. Murphy BE. Steroids and depression. J Steroid Biochem Mol Biol. 1991;38:537-59.

11. Zobel AW, Yassouridis A, Frieboes RM, Holsboer F. Prediction of medium-term outcome by cortisol response to the combined dexamethasone-CRH test in patients with remit ted depression. Am J Psychiatry.1999;156:949-51.

12. Young EA, Lopes JF, Murphy-Weinberg $\mathrm{V}$, Watson SJ, Akil H. Mineralocorticoid receptor function in major depression. Arch Gen Psychiatry. 2003;60:24-8.

13. Stefos G. [Neuroendocrine tests and sleep EEG anomalies in psychotic depression]. Acta Psychiatr Belg. 1993;93:311-21.

14. Nelson JC, Davis JM. DST studies in psychotic depression: a meta-analysis. Am J Psychiatry. 1997;154:1497-503.

15. Sapolsky RM. Depression, antidepressants, and the shirinking hippocampus. Proc Natl Acad Sci U S A. 2001;98:12320-2.

16. Aperia $B$, Thoren $M$, Zettergren $M$, Wetterberg L. Plasma pattern of adrenocorticotropin and cortisol during electroconvulsive therapy in patients with major depressive illness. Acta Psychiatr Scand. 1984;70:361-9.

17. Widerlov E, Ekman R, Jensen L, Borglund L, Nyman K. Arginine vasopressin, but not corticotropin releasing factor, is a potent stimulator of adrenocorticotropic hormone following electroconvulsive treatment. J Neural Transm. 1989;75:101-9.

18. Kronfol Z, Hamdan-Allen G, Goel K, Hill EM. Effects of single and repeated electroconvulsive therapy sessions on plasma $\mathrm{ACTH}$, prolactin, growth hormone and cortisol concentrations. Psychoneuroendocrinology. 1991;16:345-52.

19. Florkowski CM, Crozier IG, Nightingale $S$, Evans $M J$, Ellis MJ, Joyce $P$, et al. Plasma cortisol, PRL, ACTH, AVP and corticotrophin releasing hormone responses to direct current cardioversion and electroconvulsive therapy. Clin Endocrinol (Oxf). 1996;44:163-8.

20. Aperia B, Bergman $H$, Engelbrektson $K$, Thoren $M$, Wetterberg $L$. Effects of electroconvulsive therapy on neuropsychological function and circulating levels of $\mathrm{ACTH}$, cortisol, prolactin, and TSH in patients with major depressive illness. Acta Psychiatr. Scand. 1985;72:536-41.

21. Cooper SJ, Kelly JG, King DJ. Adrenergic receptors in depression. Effects of electroconvulsive therapy. Br J Psychiatry. 1985;147:23-9.

22. Aperia B. Hormone pattern and post-treatment attitudes in patients with major depressive disorder given electroconvulsive therapy. Acta Psychiatr Scand. 1986;73:271-4.
23. Weizman A, Gil-Ad I, Grupper D, Tyanos S, Laron Z. The effect of acute and repeated electroconvulsive treatment on plasma beta-endorphin, growth hormone, prolactin and cortisol secretion in depressed patients. Psychopharmacology (Berl). 1987;93:122-6.

24. Whalley LJ, Eagles JM, Bowler GM, Bennie JG, Dick HR, McGuire $\mathrm{RJ}$, et al. Selective effects of ECT on hypothalamic-pituitary activity. Psychol Med. 1987;17:319-28.

25. Smith J, Williams K, Birkett S, Nicholson H, Glue P, Nutt DJ. Neuroendocrine and clinical effects of electroconvulsive therapy and their relationship to treatment outcome. Psychol Med. $1994 ; 24: 547-55$

26. Werstiuk ES, Coote M, Griffith L, Shannon H, Steiner M. Effects of electroconvulsive therapy on peripheral adrenoceptors, plasma, noradrenaline, MHPG and cortisol in depressed patients. Br J Psychiatry. 1996;169:758-65.

27. American Psychiatric Association. Diagnostic and Statistical Manual of Mental Disorders, Fourth Edition (DSM-IV). Arlington: American Psychiatric Publishing; 1994.

28. Zis AP, Yatham LN, Lam RW, Clark CM, Srisurapanont M, McGarvey K. Effect of stimulus intensity on prolactin and cortisol release induced by unilateral electroconvulsive therapy. Neuropsychopharmacology. 1996;15:263-70.

29. Shapira B, Newman ME, Gelfin Y, Lerer B. Blunted temperature and cortisol responses to ipsapirone in major depression: lack of enhancement by electroconvulsive therapy. Psychoneuroendocrinoly. 2000;25:421-38.

30. Castro M, Moreira AC. Análise crítica do cortisol salivar na avaliação do eixo hipotálamo-hipófise-adrenal. Arq Bras Endocrinol Metab. 2003;47:358-67.

31. Schatzberg AF, Lindley S. Glucocorticoid antagonists in neuropsychiatric [corrected] disorders. Eur ] Pharmacol. 2008;583:358-64.

32. Gronli O, Stensland G $\varnothing$, Wynn R, Olstad R. Neurotrophic factors in serum following ECT: a pilot study. World J Biol Psychiatry. 2009; 10:295-301.

33. Abrams R, Taylor MA. Diencephalic stimulation and the effects of ECT in endogenous depression. Br J Psychiatry. 1976;129:4825.

34. Fink M, Nemeroff $C B$. A neuroendocrine view of ECT. Convuls Ther. $1989 ; 5: 296-304$.

35. Wolkowitz OM, Reus VI. Treatment of depression with antiglucocorticoid drugs. Psychosom Med. 1999;61:698-711.

36. Keller J, Buckluy TM, Shatzber AF. Hypothalamic-pituitaryadrenal axis activity. In: Roose SP, editor. The pychobiology of late life depression. New York: Oxford University Press; 2004. p. 157-64.

37. Fink M, Ottosson JO. A theory of convulsive therapy in endogenous depression: significance of hypothalamic functions. Psychiatry Res. $1980 ; 2: 49-61$.

38. Markianos M, Hatzimanolis J, Lykouras L. Serotonergic and dopaminergic neuroendocrine responses of male depressive patients before and after a therapeutic ECT course. Eur Arch Psychiatry Clin Neurosci. 2002;252:172-6.

39. McKay MS, Zakzanis KK. The impact of treatment on HPA axis activity in unipolar major depression. J Psychiatr Res. 2010;44:183-92.

40. Ozsoy S, Esel E, Hacimusalar Y, Candan Z, Kula M, Turan T. [Acute and chronic effects of electroconvulsive therapy on neuroactive steroids in patients with major depressive disorder]. Turk Psikiyatri Derg. 2008;19:341-8.

41. Fluitman SHA, Heijnen CJ, Denys DA, Nolen WA, Balk FJ, Westenberg HG. Electroconvulsive therapy has acute immunological and neuroendocrine effects in patients with major depressive disorder. J Affect Disord. 2011;131:388-92.

42. Sapolsky RM, Krey LC, Mcewen BS. Prolonged glucocorticoid exposure reduces hippocampal neuron number: implications for aging. J Neurosci. 1985;5:1222-7.

43. Sapolsky RM, Krey LC, McEwen BS. The neuroendocrinology of stress and aging: The glucocorticoid cascade hypothesis. Endocrine Rev. 1986; 7:284-301.

44. Pariante $\mathrm{CM}$, Miller $\mathrm{AH}$. Glucocorticoid receptors in major depression: relevance to pathophysiology and treatment. Biol Psychiatry. 2001;49:391-404.

45. Soskin DP, Cassiello $C$, Isacoff O, Fava M. The inflammatory hypothesis of depression. Focus. 2012;10:413-21.

46. Von Cauter E, Leproult R, Kupfer DJ. Effects of gender and age on the levels and circadian rhythmicity of plasma cortisol. J Clin Endocrinol Metab. 1996;81:2468-73. 
47. Harman SM. Endocrine changes with aging. UptoDate [on-line]. 2014. http://www.uptodate.com/contents/endocrine-changeswith-aging \#top

48. Young EA, Haskett RF, Murphy-Weinberg V, Watson SJ, Akil H. Loss of glucocorticoid fast feedback in depression. Arch Gen Psychiatry. 1991;48:693-9.

49. Neylan TC, Canick JD, Hall SE, Reus VI, Sapolsky RM, Wolkowitz OM. Cortisol levels predict cognitive impairment induced by electroconvulsive therapy. Biol Psychiatry. 2001;50:331-6.

50. O'Brien JT, Lloyd A, Mckeith I, Gholkar A, Ferrier N. A longitudinal study oh hippocampal volume, cortisol levels and cognition in older depressed subjects. Am J Psychiatry. 2004;161:2081-90.

\section{Correspondence:}

Daniel Fortunato Burgese

Instituto de Assistência Médica ao Servidor Público Estadual (IAMSPE)

Ambulatório de Psiquiatria

Rua Borges Lagoa, 1635

04038-034 - São Paulo, SP - Brazil

E-mail: danielburgese@yahoo.com.br 